\title{
The Construction of Gender from the Male Perspective in Moroccan Novel
}

\author{
A Sabrina ${ }^{1}$ and $\mathrm{J}$ Tjahjani ${ }^{2}$ \\ \{1annisa.sabrina@ui.ac.id; 2joesana.tjahjani@ui.ac.id\} \\ ${ }^{12}$ French Department, Universitas Indonesia
}

\begin{abstract}
The oppression of women in gender issue is one of important issues in contemporary Moroccan history (1912-1956). Driss Chraïbi conveys a resistance through the novel La Civilisation, ma Mère!... (1972) against the oppression, inferiority and pessimism of Moroccan women during the French colonization period. This article discusses the construction of gender from the male perspective in La Civilisation, ma Mère!... through the focalization of "I" who represents two sons of the mother in the novel. The method used is structural analysis with Gérard Genette's theory of narratology and Stuart Hall's concept of identity. The finding of this article shows how gender constructed through the perspective of two sons displays a criticism against patriarchal discourse. The criticism symbolizes men's narratives of woman who opposed the traditional Moroccan norms at the time and supports the presence of a woman as the force in society.
\end{abstract}

Keywords: education, gender construction, identity, Moroccan novel, narratology

\section{Introduction}

One of the important issues in contemporary Moroccan history (1912-1956) was the women's education issues [1]. In the literary work of African phonophones, freedom and education for women in the French colonial countries became an issue that was included in the discourse and practice of nationalism [2]. The Moroccan writer who is considered a pioneer in breaking the dichotomy between the positive and negative effects of colonization is Driss Chraibi. Chraibi's work is recognized as a work that not only criticizes the injustices and exploitation that occurred during the period of French colonization, but also criticizes the cultural, racial, religious, or political problems that prevented the colony to recognize Western civilization [3]. In addition, his work is not only recognized as a work that has innovative themes, but is also brave against the oppression of men against Moroccan women during the French colonization. In his novel called La Civilisation, ma Mère!... (1972), Chraïbi expressed a resistance to the oppression, inferiority and pessimism of Moroccan women during the period of French colonization [4]. The novel tells the story of a traditional Moroccan woman, the mother, who finally succeeded in pursuing knowledge, knowing modern civilization, and gaining freedom. 
There is a previous study that discusses how gender ideology in Morocco, namely an article titled Gender Differences in Religious Practices and the Association with Gender Ideology among Moroccan and Turkish Belgian Muslims [5] written by Jana A. Scheible and Fenella Fleischmann. Scheible and Fleischmann's article discusses the relationship between religiosity and gender ideology that grows among second generation Tunisian and Moroccan men and women in Belgium. In contrast to studies conducted by Scheible and Fleischmann, Touria Khannous in his article entitled Virtual Gender: Moroccan and Saudi Women's Cyberspace [6] redefined gender roles, women's legal status, discourse on feminism, sexuality, and various other problems in Morocco and Saudi Arabia. Following that, Khannous in his article entitled "Islam, Gender, and Identity in Leila Abouzeid's "The Last Chapter": A Postcolonial Critique" [7] elaborating more details about the laws that limit women, for example in marriage, divorce, and inheritance. Meanwhile, Véronica C. CobanoDelgado and Vicente Llorent-Bedmar in an article titled Identity and Gender in Childhood: Representation of Moroccan Women in Textbooks discusses how women are represented in preschool children's books in Morocco [8]. Similar to Cobano-Delgado and Llorent-Bedmar's article which uses written works in Morocco as objects of study, Gibson Ncube in his article entitled Sexual/Textual Politics: Rethinking Gender and Sexuality in Gay Moroccan Literature discusses the discourse on gender through the creation and acceptance of literary works Moroccan gays in public spaces [9]. Based on previous research that has been presented previously, it appears that construction of gender through the male point of view is a topic that is rarely examined, especially in La Civilisation, ma Mère!.... Therefore, the construction of gender in this paper is discussed through the narrator's focalization of the character that represents the two sons of the mother's character.

\section{Research Method}

The method used is structural analysis with Gérard Genette's theory of narratology and Stuart Hall's concept of cultural identity, also supported by the concept of identity of Geoffrey M. J. Chappell. According to Silke Horstkotte and Nancy Pedri in Focalization in Graphic Narrative [10], Genette divides focalization into three types, focalization zéro, focalisation externe, and focalisation interne. Focalisation zéro is the omniscient narrator, focalisation externe is the narrator's objective focalization and impartial observant, meanwhile focalisation interne is narrator's focalization which only knows and sees what the character knows and sees. Genette's focalization theory is needed to see how the narrator's perspective is used throughout the story. In Cultural Identity: A (Re)construction?, Joanne Muscat stated that Hall defines cultural identity as an identity that depends on individual experience, is always changing, not static, and is an ongoing process [11]. In addition to these perspectives, other cultural identity perspectives speak of identity as being (identities that are naturally inherent in individuals from birth to growth) and identity as becoming (identities that can be changed along with the social processes experienced by individuals). Identity as being and identity as becoming both involve how the individual who has the identity defines himself and how others define the individual. In line with the concept of identity as becoming proposed by Hall, Geoffrey M. J. Chappell in his article Identity and the Past [12] argues that individual identities cannot be separated from the collective where the individual exists. It means that cultural identity can be formed when there is interaction between the individual and the 
surrounding environment. The concept of Hall and Chappell's identity is used to see its correlation with gender construction in the text.

\section{Results And Discussion}

\subsection{Text Structure of La Civilisation, ma Mère!..}

The La Civilisation, ma Mère!... text is divided into two parts, viz Etre and Avoir. Être chapter is narrated by the character "I" who is also the narrator. The narrator-character in that chapter is the youngest son of the mother. Avoir chapter narrates Mother's character through the focalization of his eldest son, Nagib. The focalization applied in Etre and Avoir is focalisation zéro because the two narrators-characters know everything about the Mother. In $\hat{E} t r e$, the mother is narrated to portray her introduction to the modern civilization. Meanwhile in Avoir the mother is narrated as a character who has developed and evolved. The $L a$ Civilisation, ma Mère!... text can be elaborated in several sequences as shown in the picture below:
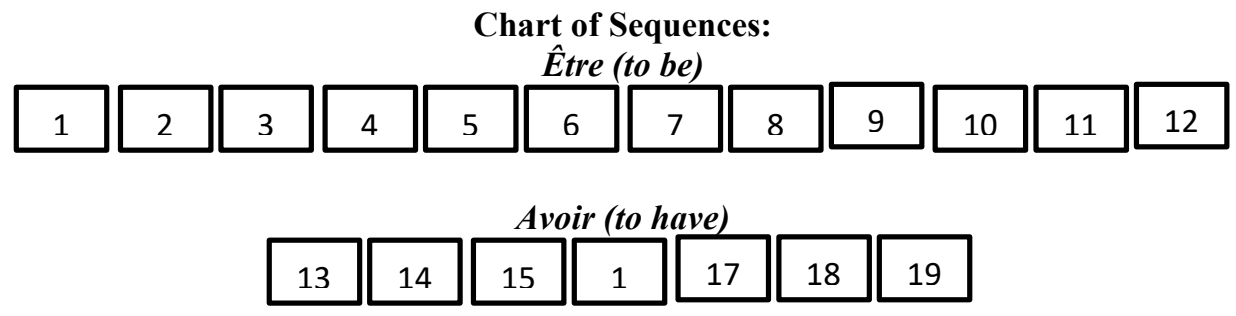

\section{Explanation:}

Etre (to be)

1. The Mother's condition before being introduced to modern civilization

2. The arrival of two people delivering the radio to "I"'s house

3. The use of term "magic box" by "I" in referring to the radio so that the object makes sense to the Mother

4. Mother's experience of conversing with the radio

5. Mother's first experience using an electric stove

6. Mother's first experience using an iron

7. Mother's first experience using the telephone

8. Mother's experience buying a new skirt when going to the park

9. Mother's decision to hide the things she bought when going to the park from the Father

10. Mother's courage to make up the continuation of the story of the film she watched in the cinema in front of the visitors

11. Mother's first experience traveling around the city

12. Mother's decision to keep her experiences outside of the house hidden from the Father

\section{Avoir (to have)}

13. Mother's intention to negotiate Moroccan independence with de Gaulle

14. Communication between the mother and one of de Gaulle's soldiers

15. Mother's courage to express her opinion to the father 
16. "I"'s experience when being advised by the mother to become the driving force of modern civilization

17. Mother's excitement in studying at the école spéciale

18. Weekly debate sessions carried out by the mother with her female friends

19. Mother's decision to go to the West

The sequence picture shows the first part of the text La Civilization, ma Mère! ..., called $\hat{E}$ tre, narrating Mother's character as a female figure in the domestic realm who is newly acquainted with modern household appliances. Meanwhile, the second part of the text titled Avoir, shows the development of the character of the mother outside the domestic sphere which carries out a series of activities in the political and educational fields.

The Etre chapter shows that the dominant events are those that describe the mother's experiences when she courageously tries to learn the modern civilization and the outside world. Some of the experiences that the character went through when she was familiar with modern civilization and the outside world then became her motivation to make major changes in society, as seen in the Avoir chapter. Therefore, through this pattern, it can be seen that in $\hat{E}$ tre chapter the mother is still described as someone who needs another subject to help her understand new things and in Avoir chapter she is described as someone who is able to rely on her own abilities.

The sequence of events in the picture also shows the characters in the text that influence the development of the mother, the youngest son, the eldest son named Nagib, and the father. Both male characters can be interpreted as factors that support the mother's character to get to know modern civilization. The youngest son figure in the $\hat{E}$ tre chapter, who attaches great importance to education, encouraged the mother to master modern civilization through education. On the other hand, the presence of father as a subject that limits mother's movement becomes the factor that triggers her counter to gain freedom. The contrasting depiction of the spatial setting in the two parts of the text, the interior space in the Etre chapter and the exterior space in the Avoir chapter can be interpreted as a symbol of the mother's success in gaining freedom. Thus, the Etre part symbolizes the existence of a mother who only controls the domestic sphere, while the Avoir symbolizes the mother as a free subject that opposes gender stereotypes.

\subsection{The Symbols of Modern Civilization in the Text}

Based on Hall [11] and Chappell's [12] concept of cultural identity that has been described previously, it appears that the interactions that influence the mother's construction of identity are the interaction between the mother's character and modern civilization. The development of the relationship between the mother and the modern civilization can certainly be seen through the objects in the text that symbolize modern civilization. The objects of modern civilization presented in the text are radio, electric stove, iron, telephone, theater, cloth, dictionary, and world map. Among the objects presented, it appears that the dominating object is the source of knowledge and a medium to communicate without boundaries and distances; such as radio, telephone, theater, dictionary, and world maps. By associating the mother character with these dominant objects, "I"'s character sees women as a worthy subject to occupy an important position in the outside world.

The objects presented before and after the mother becomes familiar with the modern civilization reflect the differences in mother's perspective on new things. Before getting to know modern civilization, the mother only gave a passive response when "I" introduced her to an object of modern civilization, as "I" says about radio in the following quote. 
«-Mais qu'est-ce que c'est cette « radio » dont j'entends parler depuis trois jours?

«-C'est une boîte qui parle. »

"- But what is "radio" that I have been hearing for the past three days?"

"- It is a talking box."

The quote above shows how the mother's ability to receive new information is still limited when it comes to something she has never met. Through the personification of the radio in the quote, it appears that the character "I" must find a way for the radio to be understood logically by the mother as an object of modern civilization. The mother's acceptance of the information given by "I"'s character about radio also shows that her character is still dependent on other subjects because she has not been able to criticize something.

After being introduced to several domestic objects that symbolize modern civilization by the character "I", the mother then begins to have openness to the objects of modern civilization that are outside the house, one of which is theater. Unlike the domestic objects that she had previously encountered, theater became an object in the outside world that symbolized the transformation of the mother's character from a woman or a passive wife into an active woman, as shown in the following quote.

«Pendant l'entracte, croquant des bonbons, elle nous raconta le film. ...S'attarda sur les détails, les creusa, intervertissant les scènes, supprimant celles qui ne lui plaisaient pas... »

"During breaks, while chewing on sweets, she narrates the film to us. ...Discuss and explore the details of the film in a prolonged manner, changing and deleting scenes that she dislikes..."

That quoted paragraph shows there was a shift between the character "I" and the mother. Mother's character is no longer a subject who only receives information, but she has also been able to provide information that involves her thoughts to other subjects. The verb raconta (told) presented in the quote can be interpreted as an intellectual development of the mother character because the word reflects an ability of someone who knows better than other subjects.

In the end, after the Mother learned various forms of technology that symbolized modern civilization, she turned into a woman who is truly independent and critical. Mother is no longer being moved by other subjects to add insight and knowledge because she already has her own an initiative to pursue insight and knowledge, as shown in the following quote.

«Au marché, elle a acheté des métrages et des mètres de tissus de couleurs différentes. Un dictionnaire d'occasion, immense, épais. Une mappemonde pour savant ambulant. "

"At the market, she bought a recording device and several meters of fabric in different colors. A used, large, thick dictionary. A map of the world for traveling."

The quote shows that the mother has viewed knowledge as a necessity. Through objects such as dictionnaire (dictionary) and mappemonde (world map) presented in the quotation, it appears that the mother has a desire to explore and enrich knowledge in depth and continuously without having to be motivated in advance by her two sons. In other words, the objects presented can be interpreted as the stage where the mother character is able to carry out the process of confirmation and exploration when receiving new information, not merely accepting the information and sharing it. 
Based on the notions showing the relationship state between the mother and the modern civilization, the gender construction carried out by her two sons indeed shows that modern civilization is a factor that drives the mother's character to have openness to the outside world and responds to her curiosities. However, modern civilization is not entirely a factor that drives change in her character, since the biggest factor driving that change is her determination to do things according to her beliefs. Determination of the mother's character to do things in line with her desire was initially not described as enough because her character is still in the stage of recognizing the outside world. However, her determination is later described as having more value when the presence of her character has become something meaningful to other subjects. Through this description, it appears that the novel $L a$ Civilization, ma Mere! ... is out of the pattern of other Chraïbi's works. This novel not only criticizes injustice and exploitation in Morocco during the period of French colonization, but also specifically seeks to present Moroccan women as a capable force of rivaling men.

\subsection{Identity Construction of a Woman Figures}

As seen in the discussion about the structure of the text, the two parts of La Civilisation, ma Mere!... text shows the construction of the mother's identity which associated with the problem of existence. In his book To Have or to Be? [13], Erich Fromm argues there are three basic concepts of existence, they are the existence of being and possessions which cannot be separated from each other, the existence of possessing elements which determines the elements of being, as well as the existence of elements of individual authenticity and existence that refer to the true reality of the individual. If associated to the Fromm's concept of existence, the La Civilisation, ma Mère!... text equalizing the Etre and Avoir parts as the process of forming the mother's existence. The Etre chapter, which should depict the element to be, shows how the mother interprets objects that symbolize modern civilization. On the contrary, the Avoir chapter (the element of possessing) is precisely the part that shows the existence of the mother as a female activist.

Meanwhile, the condition of the mother who previously felt strange seeing the outside world was closely related to the condition of women in Morocco at that time, precisely in the 1930s. In line with what Christine Chevalier-Caron explained in the article entitled Femmes, éducation, et identités au Maroc sous domination française (1862-1962) [1], Educational discrimination for Moroccan women during the French Protectorate eventually led to Moroccan women's resistance to patriarchal culture. When Mother's character has been touched by modern civilization, her character's positioning does not stop at her acceptance of the outside world because there is a further impact produced by that acceptance. The part of the text in question can be seen in the following quotation.

«-Je ne te reconnais plus, je ne te comprends plus... »

«-...C'est difficile, dis-tu? Impossible? Peut-Être, mais je peux le faire. Je peux tout

faire. "

“- I don't know you anymore, I don't understand you anymore..."

"- Difficult, you say? Impossible? Maybe, but I can do it. I can do everything."

The quote is utterance made by the mother after the father said that she had become someone who was very different and strange. The way the words je peux was written with different format can be interpreted as the mother's realization of her rights to have equal opportunities as men. Those words can also be interpreted as the mother's courage to escape from the expectations of her husband towards Moroccan women and to become a subject that no longer depends on anyone. 
In accordance with Morocco's social conditions that have been described by ChevalierCaron [1], the mother became a representation of the liberation of Moroccan women in the 1930s because she was in the process of becoming a woman who knew modern civilization and education. Even though the mother's encounter with the outside world is bridged by the presence of her two sons, her character still controls and develops her own insights. This is as depicted in the following quote.

«Dès le lendemain matin, elle téléphona a sa cousine. Si elle parla de sa robe neuve, de ses souliers, du parc, de la verdure...»

"The next morning, she called her cousin. She talked about her new skirt clothes, shoes, garden, greenery..."

The quote above shows that the character "I" views the mother as a character who is not only familiar with technology, but also a person who can use technology to express the happiness and pride she gets from her experiences. The pride and happiness expressed by the mother can be seen as acceptance of the outside world since she has grown positive feelings in finding things that are not normally found in the house. Objects such as robe neuve (a new dress) and souliers (the shoes) can be interpreted as the mother's fulfilled material desires, which she was unable to get when her life was still limited by the walls of the house. Both objects can also be interpreted as the acceptance of the mother to the modernity of the west because there is a possibility that both their features and forms are different from traditional Moroccan styles, given that Morocco at that time had received a lot of influence from the French Protectorate.

In line with the positioning of the mother through direct speech, the position of the mother in the eyes of her son also shows that the narrator-character "I" as Moroccan men no longer view the presence of women outside the home as taboo. "I"'s view of a woman implicitly represents a criticism against patriarchal discourse because it views women as subjects who have the right to be free. The presentation of this view became a form of criticism of the social conditions of Morocco which at the time restricted women to adopt modern civilization and pursue education. Through this criticism, it appears that La Civilization, ma Mère! ... can be positioned as the voice of Moroccan women during the period of French colonization, particularly the right to recognize modern civilization and the right to have education [14].

\section{Conclusion}

Through the presented series of analysis, it can be concluded that the identity as being of the mother in La Civilisation, ma Mère!... text is the identity of a traditional Moroccan woman who was initially trapped in a patriarchal culture. Identity as becoming, which then emerged in the mother's character, is an identity as a Moroccan woman who is free in Western perspective. The Etre chapter in the text shows the existence of the mother in the process of identity as being as a woman who is open to modern civilization, while the Avoir part emphasizes the position of the mother character in the concept of identity as becoming as a free subject, which shows the determination of Moroccan woman. In line with the identity as becoming emerging in the mother's character, construction of gender through the perspective of the two sons indeed shows a criticism against patriarchal discourse because the Etre and Avoir parts both present the mother character as a Moroccan woman who has the determination to be a free subject. Through the criticism against patriarchal discourse, it 
appears that the construction of gender from the perspective of men in the novel $L a$ Civilization, ma Mère! ... symbolizes men's narratives about a woman who oppose traditional Moroccan norms at the time and support the presence of a woman as a force in society. Therefore, in line with the criticism of patriarchal discourse in the novel, a further study of this research is the influence of Moroccan women in the public sphere after the French occupation.

\section{References}

[1] C. Chevalier-Caron, "Femmes, Éducation Et Identités Au Maroc Sous Domination Française (1862-1962)," Université Du Québec À Montréal, 2016.

[2] A. A. Coly, The Pull of Postcolonial Nationhood: Gender and Migration in Francophone African Literatures. Maryland: Lexington Books, 2010.

[3] K. Moser, "A 'Better Life'? The universal deception of immigrants in the narratives of Driss Chraïbi and J. M. G. Le Clézio,” Int. J. Francoph. Stud., vol. 16, no. 1\&2, pp. 9-26, 2013.

[4] V. K. Orlando, Francophone Voices of the "New" Morocco in Film and Print, 1st ed. New York, USA: Palgrave Macmillan ${ }^{\circledR}, 2009$.

[5] J. A. Scheible and F. Fleischmann, "Gendering Islamic Religiosity in the Second GenerationGender Differences in Religious Practices and the Association with Gender Ideology among Moroccan- and Turkish-Belgian Muslims," Gend. Soc., vol. 27, no. 3, pp. 372-395, 2013.

[6] T. Khannous, "Virtual Gender: Moroccan and Saudi Women's Cyberspace," J. Women Middle East Islam. World, vol. 8, pp. 358-387, 2011.

[7] T. Khannous, "Islam, Gender, and Identity in Leila Abouzeid's " The Last Chapter ". A Postcolonial Critique," Coll. Lit., vol. 37, no. 1, pp. 174-189, 2010.

[8] V. C. Cobano-Delgado and V. Llorent-Bedmar, "Identity and gender in childhood. Representation of Moroccan women in textbooks," Womens. Stud. Int. Forum, vol. 74, no. November 2018, pp. 137-142, 2019.

[9] G. Ncube, "Sexual/textual politics: rethinking gender and sexuality in gay Moroccan literature," J. Contemp. African Stud., vol. 32, no. 4, pp. 476-490, 2014.

[10] S. Horstkotte and N. Pedri, "Focalization in Graphic Narrative," Narrative, vol. 19, no. 3, pp. 330-357, 2011.

[11] J. Muscat, "Cultural Identity - A (Re) construction?," Int. J. Humanit. Soc. Sci., vol. 7, no. 6, pp. 1664-1667, 2013.

[12] G. M. J. Chappell, "Identity and the Past," Meet. Minds Grad. Student J. 1, vol. 1, pp. 1-12, 2017.

[13] E. Fromm, To Have or To Be? London, New York: Continuum, 2008.

[14] K. Saddhono and M. Rohmadi, "A Sociolinguistics Study on the Use of the Javanese Language in the Learning Process in Primary Schools in Surakarta, Central Java, Indonesia." Int. Edu. Stu., vol. 7 no.6 pp 25-30, 2014 